\title{
Ocena wyrównania metabolicznego u chorych na cukrzycę typu 2 pracujących w systemie zmianowym
}

\author{
Metabolic control in type 2 diabetic patients working shift patterns
}

\section{STRESZCZENIE}

Wstęp. Cukrzyca typu 2 jest chorobą przewlekłą o wzrastającej tendencji do występowania na całym świecie. Stanowi $90 \%$ wszystkich typów cukrzycy i jest związana z otyłością i insulinoopornością. Jej leczenie wymaga redukcji masy ciała, regularnego wysiłku fizycznego oraz przyjmowania leków. Regularność ta może zostać zaburzona, kiedy rytm dobowy ulega wahaniom w zależności od formy zatrudnienia. Interesującą kwestią wydaje się związek pracy zmianowej i wyrównania metabolicznego.

Materiał i metody. Badanie zostało przeprowadzone w grupie 194 pacjentów chorych na cukrzycę typu 2 (skutecznie leczonych przynajmniej przez 6 miesięcy doustnymi lekami przeciwcukrzycowymi), ankietowanych w okresie od października 2014 roku do marca 2015 roku w poradniach diabetologicznych na terenie Zabrza, Tarnowskich Gór i Chrzanowa. Kryteria włączenia: cukrzyca typu 2, chory aktywny zawodowo. Pacjenci zostali poproszeni o wypełnienie anonimowej ankiety składającej się z 20 pytań, obejmującej dane ogólne oraz szczegółowe dotyczące wyrównania cukrzycy, czasu pracy w systemie zmianowym, stylu życia, powikłań, zaburzeń snu oraz jakości życia. Bada-

Adres do korespondencji:

Katarzyna Zielińska

Oddział Kliniczny Chorób Wewnętrznych i Diabetologii

III Katedra i Oddział Kliniczny Kardiologii ŚUM

Śląskie Centrum Chorób Serca w Zabrzu

e-mail: katarzynaxzielinska@gmail.com

Diabetologia Kliniczna 2015, tom 4, 4, 132-140

DOI: 10.5603/DK.2015.0013

Nadesłano: 30.06.2015

Przyjęto do druku: 16.09.2015 nych podzielono na dwie grupy: pracujących $(n=94)$ i niepracujących $(n=100)$ w systemie zmianowym. Otrzymane dane zostały przeanalizowane przy użyciu programu Statistica 12.0.

Wyniki. U chorych pracujący zmianowo glikemia na czczo była wyższa - $130 \mathrm{mg} / \mathrm{dl}$ vs. $121 \mathrm{mg} / \mathrm{dl}$ ( $p<0,034)$, jakość snu gorsza $-7,78$ vs. 5,21 pkt w Skali Ateńskiej ( $p<0,0002)$, a ocena jakości życia niższa $-6,0$ vs. 6,8 pkt ( $p<0,007$ ). Hemoglobina glikowana $\left(\mathrm{HbA}_{1 \mathrm{c}}\right)$, indeks masy ciała (BMI) oraz czas trwania insulinoterapii nie różniły się istotnie statystycznie między grupami. W badanej grupie częściej pojawiały się zaburzenia lipidowe oraz występowała mniejsza regularność w spożywaniu posiłków.

Wnioski. Praca zmianowa w niewielkim stopniu wpływa na wyrównanie glikemii u chorego na cukrzycę typu 2 . Natomiast zaburzając rytm okołodobowy, oddziałuje na jakość życia, jakość snu oraz regularność spożywania posiłków u chorego na cukrzycę typu 2. W związku z tym leczenie pacjenta chorego na cukrzycę typu 2 pracującego w systemie zmianowym może okazać się szczególnie wymagające. (Diabet. Klin. 2015; 4, 4: 132-140)

Słowa kluczowe: praca zmianowa, cukrzyca typu 2, wyrównanie metaboliczne, glikemia, jakość snu

\section{ABSTRACT}

Introduction. Type $\mathbf{2}$ diabetes is a chronic disease with tendency to increase throughout the world. It represents $90 \%$ of all diabetes and is associated with obesity and insulin resistance. Treatment of diabetes requires weight loss, regular physical activity and intake of 
medicines. This regularity can be disturbed if the circadian rhythm fluctuates, depending on the form of employment. An interesting issue is the relationship between shift work and metabolic control.

Material and methods. The survey was conducted among group of 194 patients with type 2 diabetes (successfully treated for at least six months with oral antidiabetic drugs) from October 2014 to March 2015 in diabetes clinics in Zabrze, Tarnowskie Góry and Chrzanów. The inclusion criteria: type 2 diabetes, employed and working patient. Patients were asked to complete the anonymous questionnaire composed of 20 questions, including general information and details about diabetes control, working hours, lifestyle, health complications, sleep disorders and quality of life. Patients were divided into two groups: shift workers $(n=94)$ and non-shift workers $(n=100)$. The collected data was analyzed with Statistica 12.0.

Results. Patients who work shifts had higher fasting blood glucose $-130 \mathrm{mg} / \mathrm{dl}$ vs. $121 \mathrm{mg} / \mathrm{dl}$ ( $p<0.034)$, lower quality of sleep -7.78 vs. 5.21 points on the Athens Scale $(p<0.0002)$ and lower quality of life -6.0 vs. 6.8 points $(p<0.007)$. Glycated hemoglobin $\left(\mathrm{HbA}_{1 \mathrm{c}}\right)$, body mass index (BMI) and the duration of insulin therapy were not significantly different between the groups. In the study group more often appeared lipid disorders and there was less regularity in eating meals. Conclusions. Shift work has little effect on glycemic control in type 2 diabetic patient. However, disrupting the circadian rhythm, affects the quality of life, quality of sleep and regularity of eating in patients with type 2 diabetes. Therefore, the treatment of type 2 diabetic patient working shifts, can be particularly demanding. (Diabet. Klin. 2015; 4, 4: 132-140)

Key words: shift work, type 2 diabetes, metabolic control, glycemia, quality of sleep

\section{Wstęp}

Cukrzyca typu 2 to przewlekła choroba, której częstość występowania na świecie ciągle rośnie [1]. Stanowi ona około $90 \%$ wszystkich przypadków cukrzycy, a jej rozwój jest wyraźnie związany z czynnikami środowiskowymi, tzn. otyłością brzuszną oraz małą aktywnością fizyczną [2]. Prowadzi to do rozwoju insulinooporności i ostatecznie do wyczerpania możliwości wydzielniczych komórek $\beta$ trzustki [3].

Dlatego leczenie cukrzycy wymaga z jednej strony redukcji masy ciała i regularnej aktywności fizycznej, z drugiej zaś stosowania leków. W momencie, kiedy rytm dobowy ulega wahaniom w zależności od formy zatrudnienia, regularność ta może ulec zaburzeniu [4].
Postęp techniczny, jaki nastąpił w ostatnim stuleciu, i możliwość korzystania ze sztucznego oświetlenia spowodowały odejście od naturalnego rytmu życia. W ostatnich latach rośnie liczba pracowników zmianowych. W Europie ta forma zatrudnienia dotyczy około $15-20 \%$ siły roboczej. Ten tryb pracy wiąże się $z$ wieloma problemami zdrowotnymi, spowodowanymi zachwianiem rytmów biologicznych $[2,5,6]$. Wykazano związek między pracą zmianową a zwiększonym ryzykiem otyłości i rozwoju zespołu metabolicznego oraz zaburzeniami metabolizmu glukozy. W kilku publikacjach udowodniono także zwiększone ryzyko rozwoju cukrzycy typu 2 [7-9].

Część pacjentów pracujących zmianowo to chorzy na cukrzycę typu 2. W związku z tym istotne wydaje się określenie potencjalnego oddziaływania takiej formy zatrudnienia na chorego [10]. Celem niniejszej pracy była próba odpowiedzi na pytanie, czy praca zmianowa wpływa na wyrównanie metaboliczne pacjenta chorującego na cukrzycę typu 2, oraz ocena związanych z tym trudności terapeutycznych.

\section{Materiał i metody}

Badanie zostało przeprowadzone w grupie 194 pacjentów chorych na cukrzycę typu 2, ankietowanych w okresie 6 miesięcy (od października 2014 do marca 2015) w poradniach diabetologicznych na terenie Zabrza, Tarnowskich Gór i Chrzanowa pod nadzorem badających. Jako kryteria włączenia przyjęto: cukrzycę typu 2 oraz aktywność zawodową. Pacjenci zostali poproszeni o wypełnienie anonimowej ankiety składającej się z 21 pytań, obejmującej dane ogólne oraz szczegółowe dotyczące m.in. wyrównania cukrzycy, czasu pracy w systemie zmianowym, stylu życia, powikłań, zaburzeń snu (wg Skali Ateńskiej) oraz jakości życia (skala graficzna 1-100) (ryc. 1)

Ankietowanych podzielono na 2 grupy: pracujących w systemie zmianowym oraz niepracujących w systemie zmianowym. Otrzymane dane zostały przeanalizowane przy użyciu programu Statistica 12.0.

W celu porównań międzygrupowych użyto testu t-Studenta dla danych parametrycznych i $\chi^{2}$ przy analizie liczebności.

\section{Wyniki}

W badaniu wzięły udział 194 osoby, które zostały podzielone na 2 grupy: pracujących w systemie zmianowym ( $\mathrm{n}=94$ ) oraz niepracujących zmianowo ( $n=100$ ). Podstawowa charakterystyka obu grup znajduje się $w$ tabeli 1 . Chorzy pracujący zmianowo byli młodsi od chorych niepracujących zmianowo ( $p<0,05)$, natomiast czas trwania cukrzycy (pracowni- 


\section{ANKIETA}

Nr kartoteki

Wiek............. Waga

Wzrost.

Czas trwania cukrzycy...

Czas leczenia insuliną...

$\square$ Nie dotyczy

Glikemia na czczo, średnia z 3 pomiarów.

$\mathrm{HbA}_{1 \mathrm{c}}$

Glikemia po posiłku, średnia z 3 pomiarów.

1. Czy jest Pan/Pani pracownikiem: $\square$ Fizycznym $\square$ Umysłowym

2. Czy jest Pan/Pani pracownikiem zmianowym? $\square$ Tak $\square$ Nie

3. Płeć: $\square$ Kobieta $\square$ Mężczyzna

4. Stan cywilny: $\square$ Wolny $\square$ Zamężna/żonaty

5. Wykształcenie: $\square$ Podstawowe $\square$ Średnie $\square$ Wyższe

6. Jak długo pracuje Pan/Pani w systemie zmianowym?

$\square \quad 1-5$ lat

$\square \quad$ 5-10 lat

$\square$ Powyżej 10 lat

7. Czy według Pana/Pani zmienne godziny pracy naruszają prawidłowe funkcjonowanie organizmu? $\quad \square$ Tak $\quad \square$ Nie

8. Czy od momentu rozpoczęcia pracy w systemie zmianowym zauważył/-a Pan/Pani zmiany w funkcjonowaniu organizmu?

$\square \quad$ Nie

$\square$ Tak, które:

$\square$ Praca serca $\square$ Układu pokarmowego $\square$ Oddawanie moczu lub stolca

$\square$ Praca układu nerwowego $\square$ Układu hormonalnego

$\square$ Inne:

9. Czy praca zmianowa jest dla Pana/Pani czynnikiem stresogennym?

$\square$ Tak $\square$ Nie

10. Jakiego rodzaju zaburzenia odczuwa Pan/Pani od momentu podjęcia pracy w systemie zmianowym?

$\square$ Zaburzenia snu, brak koncentracji, zmęczenie

$\square$ Rozdrażnienie

$\square \quad$ Apatia

$\square$ Stany lękowe

$\square \quad$ Nerwowość

$\square$ Zaburzenia funkcjonowania społecznego

$\square$ Większe spożycie kawy

$\square \quad$ Większe spożycie alkoholu

$\square$ Spożywanie leków nasennych, uspokajających

$\square \quad$ Nasilenie palenia tytoniu

$\square$ Zwiększona podatność na choroby

$\square$ Depresja

$\square$ Inne:

11. Czy od rozpoczęcia pracy w systemie zmianowym wzrosła u Pana/Pani masa ciała?

$\square \quad$ Tak, o ile kg

$\square \quad$ Nie

12. Czy w trakcie pracy zmianowej zdarzały się u Pana/Pani incydenty hipoglikemii?

$\square$ Tak: $\square$ Lekkie $\square$ Ciężkie

$\square \quad$ Nie

13. Czy po rozpoczęciu pracy zmianowej została u Pana/Pani zdiagnozowana jakakolwiek choroba?

$\square \quad$ Tak, jaka

$\square \quad$ Nie

14. Czy objawy pojawiły się dopiero po rozpoczęciu pracy w systemie zmianowym?

$\square$ Tak $\square$ Nie

15. Jaki jest poziom Pana/Pani aktywności fizycznej?
$\square$ Niski
$\square$ Średni
$\square$ Wysoki

16. Czy cierpi Pan/Pani z powodu innych chorób?

$\square$ Nadciśnienie $\square$ Wysoki cholesterol/trójglicerydy $\square$ Choroba wieńcowa

$\square$ Inne

$\square$ Nie

17. Czy posiłki spożywa Pan/Pani regularnie? $\square$ Tak $\square$ Nie

18. Czy spożywa Pan/Pani alkohol?

$\square$ Tak, ile, jaki, jak często.

$\square$ Nie 


\section{ANKIETA}

19. Czy pali Pan/Pani papierosy?

$\square$ Tak, ile, od kiedy.

$\square$ Nie

$\square$ Były palacz

20. Ateńska Skala Bezsenności:

Proszę zakreślić numer przy haśle odpowiadającym wymienionym poniżej objawom, jeśli objawy te występowały

co najmniej trzy razy w tygodniu w ciągu ostatniego miesiąca.

* Zasypianie po położeniu się do łóżka i zgaszeniu światła:

0. szybkie

1. nieznacznie opóźnione

2. opóźnione

3. bardzo opóźnione lub bezsenność przez całą noc

* Budzenie się podczas nocy:

0 . nie występuje

1. sporadycznie

2. często

3. bardzo często lub bezsenność przez całą noc

* Budzenie się rano wcześniej niż planowano:

0 . o zamierzonej godzinie

1. nieznacznie wcześniej

2. znacznie wcześniej

3. dużo wcześniej lub bezsenność przez całą noc

* Całkowity czas snu:

0 . wystarczający

1. nieznacznie niewystarczający

2. wyraźnie niewystarczający

3. całkowicie lub bezsenność przez całą noc

* Jakość snu niezależnie od czasu jego trwania:

0 . satysfakcjonująca

1. nieznacznie niesatysfakcjonująca

2. wyraźnie niesatysfakcjonująca

3. całkowicie niesatysfakcjonująca

* Samopoczucie następnego dnia:

0 . dobre

1. nieznacznie gorsze

2. wyraźnie gorsze

3. wybitnie gorsze

* Sprawność psychiczna i fizyczna następnego dnia:

0 . niezaburzona

1. nieznacznie zaburzona

2. wyraźnie zaburzona

3. wybitnie zaburzona

* Senność w ciągu dnia:

0 . nie zdarza się

1. nieznacznie nasilona

2. wyraźnie nasilona

3. bardzo nasilona

Skala Ateńska

punktów.

21. Ocena jakości życia.

Chcielibyśmy, aby Pan/Pani określit/-a obecny stan swojego zdrowia w skali od 1 do 10, gdzie 10 to najlepszy wyobrażalny stan zdrowia, a 1 to najgorszy wyobrażalny stan zdrowia.

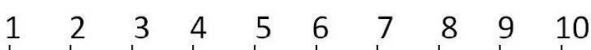

Rycina 1. Ankieta przeprowadzona u pacjentów chorych na cukrzycę 
Tabela 1. Charakterystyka badanych grup chorych

Pracownicy zmianowi Pracownicy niezmianowi

p

$(n=94)$

$(n=100)$

Wiek (lata), średnia \pm SD

$51,7( \pm 7,34)$

$55,3( \pm 6,86)$

$<0,05$

Wskaźnik masy ciała (BMI) $\left[\mathrm{kg} / \mathrm{m}^{2}\right]$, średnia $\pm \mathrm{SD}$

$31,4( \pm 4,62)$

$30,8( \pm 4,34)$

NS

Czas trwania cukrzycy (lata), średnia \pm SD

$8,17( \pm 6,90)$

$7,23( \pm 5,43)$

NS

Czas trwania insulinoterapii (lata), średnia \pm SD

$2,56( \pm 4,91)$

$2,75( \pm 5,05)$

NS

Płeć M:K (n)

44:50

$36: 64$

Alkohol, n (\%)

$57(60,6)$

56 (56)

NS

Tytoń, n (\%)

$35(37,2)$

28 (28)

NS

$<0,05$

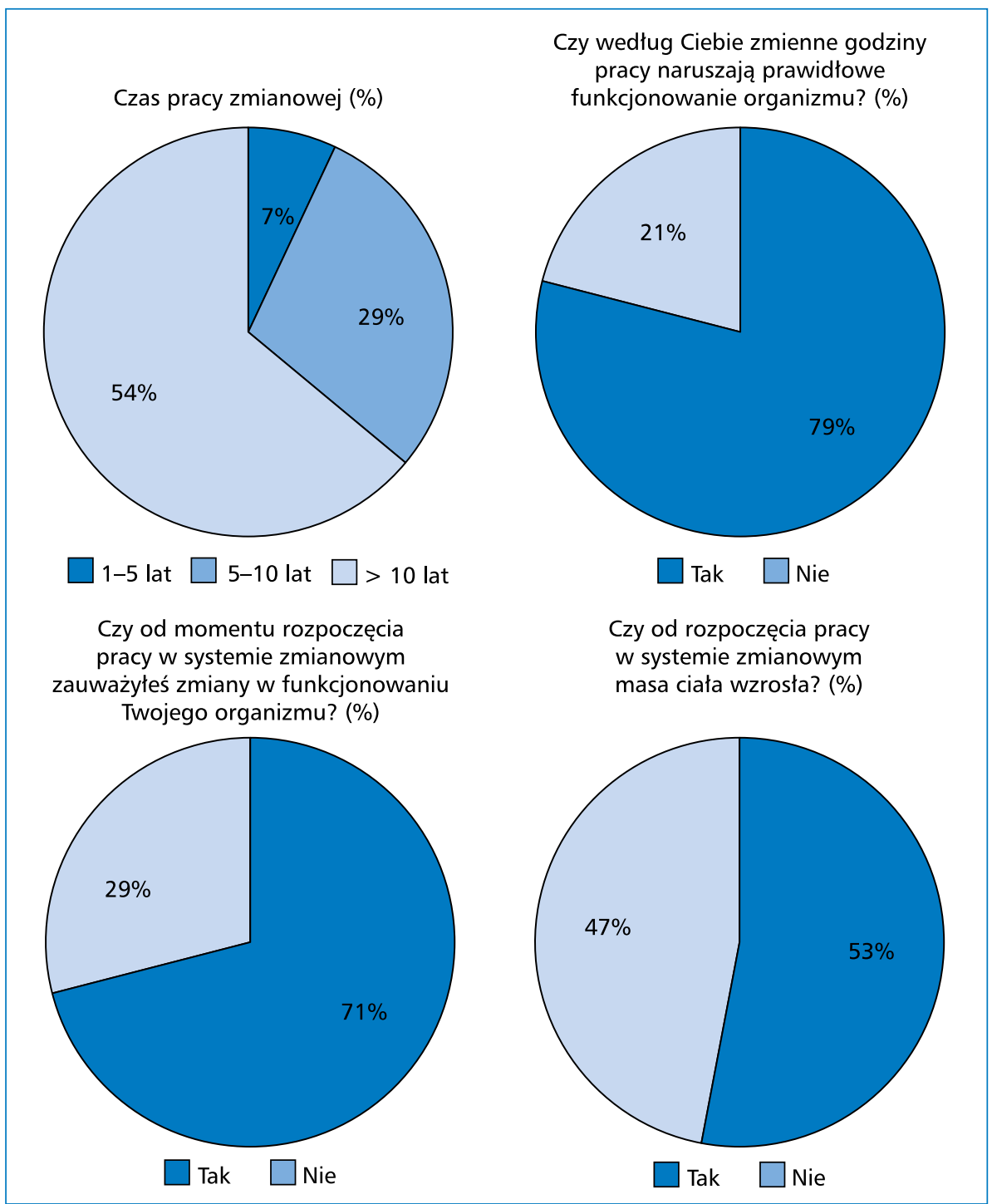

Rycina 2. Ocena czasu trwania pracy zmianowej, funkcjonowania organizmu oraz wzrostu masy ciała

cy zmianowi 8,17 $\pm 6,90$ roku; pracownicy niezmianowi $7,23 \pm 5,43$ roku) oraz czas trwania insulinoterapii (pracownicy zmianowi 2,56 $\pm 4,91$ roku; pracownicy niezmianowi $2,75 \pm 5,05$ roku) nie różnił się istotnie między grupami.
Respondenci deklarujący pracę w systemie zmianowym odpowiadali na dodatkowe pytania dotyczące czasu trwania pracy zmianowej, samopoczucia w okresie pracy oraz pojawienia się zaburzeń w funkcjonowaniu organizmu i zwiększenia masy ciała (ryc. 2). Spośród ba- 
Tabela 2. Zaburzenia u pracowników zmianowych

\begin{tabular}{lcc}
\hline Rodzaje zaburzeń & Suma & Odsetek \\
\hline Zaburzenia snu, brak koncentracji, zmęczenie & 52 & $55,3 \%$ \\
Rozdrażnienie & 42 & $44,7 \%$ \\
Apatia & 11 & $11,7 \%$ \\
Stany lękowe & 6 & $6,38 \%$ \\
Nerwowość & 44 & $46,8 \%$ \\
Zaburzenia funkcjonowania społecznego & 6 & $6,38 \%$ \\
Większe spożycie kawy & 44 & $46,8 \%$ \\
Większe spożycie alkoholu & 5 & $5,31 \%$ \\
Spożywanie leków nasennych, uspokajających & 8 & $8,51 \%$ \\
Nasilenie palenia tytoniu & 19 & $20,2 \%$ \\
Zwiększona podatność na choroby & 22 & $23,4 \%$ \\
Depresja & 4 & $4,26 \%$ \\
\hline
\end{tabular}

Tabela 3. Porównanie wyników podstawowych parametrów oceny cukrzycy, Ateńskiej Skali Bezsenności oraz jakości życia w obu grupach badanych

\begin{tabular}{lccc}
\hline & Pracownicy zmianowi & Pracownicy niezmianowi & p \\
\hline Glikemia na czczo $[\mathrm{mg} / \mathrm{dl}]$, średnia \pm SD & $130( \pm 25,0)$ & $121( \pm 30,8)$ & 0,034 \\
Glikemia poposiłkowa $[\mathrm{mg} / \mathrm{dl}]$, średnia \pm SD & $150( \pm 28,4)$ & $148( \pm 40,2)$ & $\mathrm{NS}$ \\
$\mathrm{HbA}_{1 c}(\%)$, średnia \pm SD & $7,03( \pm 0,64)$ & $7,19( \pm 0,84)$ & $\mathrm{NS}$ \\
Ateńska Skala Bezsenności, średnia liczba punktów \pm SD & $7,78( \pm 5,02)$ & $5,21( \pm 4,24)$ & 0,0002 \\
Ocena jakości życia, średnia liczba punktów \pm SD & $61( \pm 16,6)$ & $68( \pm 15,5)$ & 0,007 \\
\hline
\end{tabular}

danych $7 \%$ pracuje zmianowo $1-5$ lat, $29 \%-5-10$ lat, natomiast $64 \%$ - powyżej 10 lat. Według $79 \%$ badanych zmienne godziny pracy naruszają prawidłowe funkcjonowanie organizmu. Aż 71\% chorych od momentu rozpoczęcia pracy $w$ systemie zmianowym zauważyło zmiany w funkcjonowaniu organizmu (tab. 2). Dla 55\% praca zmianowa jest czynnikiem stresogennym. U 53\% ankietowanych masa ciała wzrosła od czasu podjęcia zatrudnienia $w$ tej formie.

Wykazano istotnie wyższą ( $p<0,034)$ glikemię na czczo w grupie pracowników zmianowych: $130 \pm 25 \mathrm{mg} / \mathrm{dl}$, w porównaniu z osobami z drugiej grupy: $121 \pm 31 \mathrm{mg} / \mathrm{dl}$. Średni wskaźnik masy ciała (BMI, body mass index), hemoglobina glikowana $\left(\mathrm{HbA}_{1 \mathrm{c}}\right)$ oraz glikemia poposiłkowa nie różniły się.

Analiza Ateńskiej Skali Bezsenności wskazuje na wyższą punktację u pracowników zmianowych $(7,78 \pm 5,02$ pkt w porównaniu z 5,21 \pm 4,24 pkt; p < 0,0002), co świadczy o wyraźnie częstszym występowaniu zaburzeń snu w tej grupie. Odsetek osób z grupy pracowników zmianowych z wynikiem $\geq 8$ pkt wynosił $51 \%(n=48)$. Jest to wartość pozwalająca z wysokim prawdopodobieństwem wnioskować o występowaniu bezsenności nieorganicznej według kryteriów Międzynarodowej Klasyfikacji Chorób ICD-10 [11].
Średnia ocena jakości życia była istotnie niższa w grupie pracowników zmianowych: 60,9 \pm 16,6 pkt vs. $68,0 \pm 15,5$ pkt w drugiej grupie $(p<0,007)$ (tab. 3). Ponadto respondenci pracujący zmianowo w $61 \%$ deklarowali spożycie alkoholu oraz w 37\% palenie tytoniu. Jest to odsetek wyższy niż w grupie niepracującej zmianowo (spożycie alkoholu 56\%, palenie tytoniu 28\%). Odnotowano także znacznie gorszą regularność w spożywaniu posiłków u pracujących zmianowo: 19\% twierdzi, że je regularnie. Ten odsetek w drugiej grupie wynosi $52 \%$. W grupie pracowników zmianowych 30,85\% określiło swoją aktywność fizyczną jako niską, $45 \%$ jako średnią, a 24\% jako wysoką; u pracowników niezmianowych kolejno: 34\% — niska aktywność, 48\% — średnia, $18 \%$ - wysoka (ryc. 3). Takie wyniki mogą zapewne się wiązać z charakterem pracy zmianowej (w $65 \%$ była to praca fizyczna, natomiast praca w trybie dziennym miała charakter pracy fizycznej w 43\%).

\section{Dyskusja}

Cukrzyca typu 2 jest chorobą zmieniającą się dynamicznie, wymagającą modyfikacji postępowania w zależności od aktualnej sytuacji patofizjologicznej. Kluczową kwestią jest zmiana stylu życia i minimalizowanie negatywnych czynników środowiskowych. 


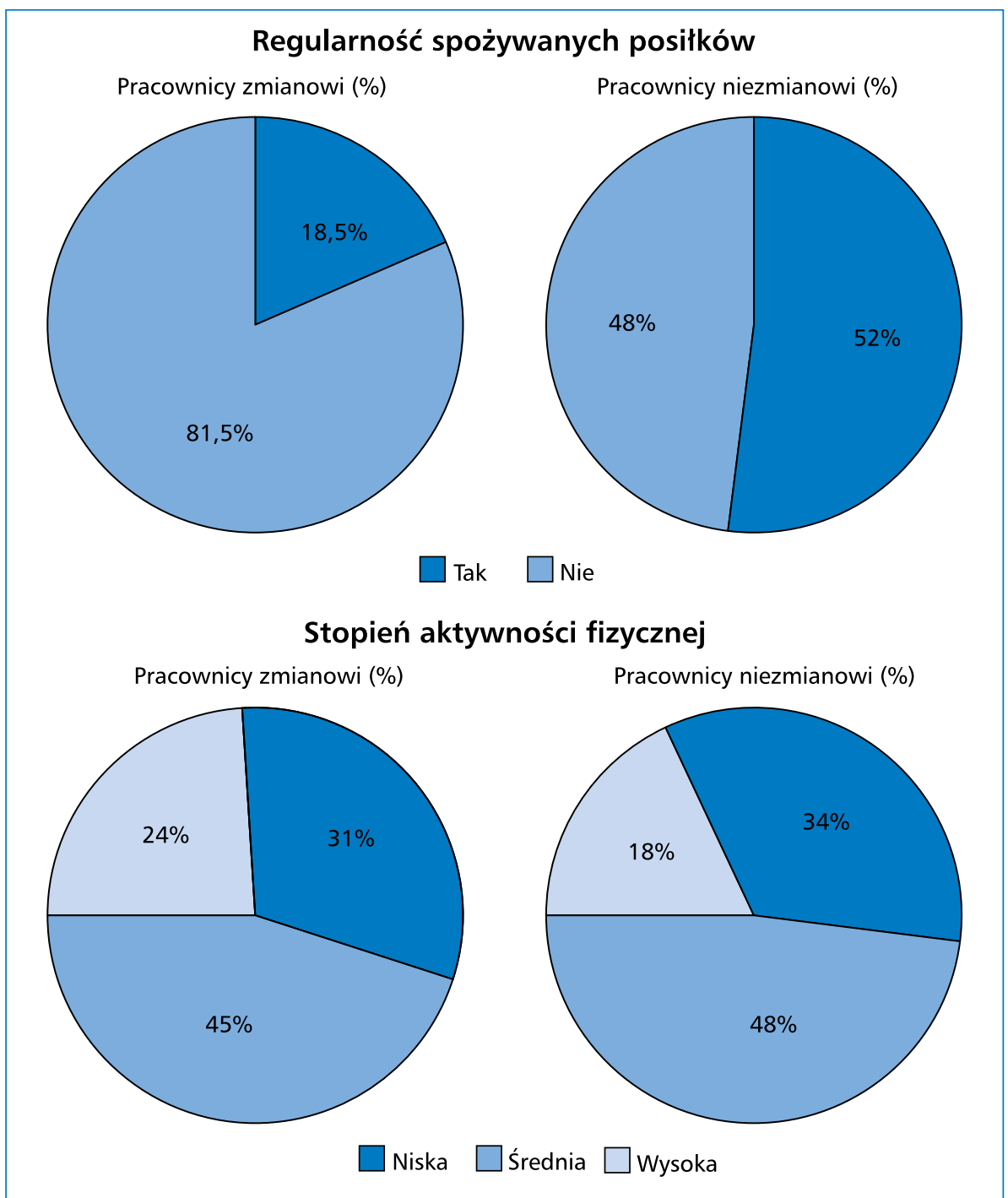

Rycina 3. Porównanie regularności spożywania posiłków oraz stopnia aktywności fizycznej w obu grupach badanych

Pacjent pracujący zmianowo boryka się z trudnościami w przestrzeganiu diety oraz rytmu leczenia. Naturalny dobowy rytm aktywności zostaje zaburzony. Ponadto w organizmie zachodzi wiele niekorzystnych zmian o potencjalnym działaniu diabetogennym. Może to utrudniać wyrównanie metaboliczne chorego oraz przyspieszać rozwój choroby.

Metaanaliza danych zgromadzonych między rokiem 1983 a 2013 potwierdziła zwiększone ryzyko rozwoju cukrzycy typu 2 u pracowników zmianowych [12]. Wiąże się to z występowaniem zaburzeń snu, wzrostem masy ciała czy zmianami behawioralnymi. Można z tego wnioskować, że u pacjenta chorego na cukrzycę typu 2 pracującego zmianowo powyższe czynniki nadal będą występowały i mogą mieć wpływ na przebieg choroby.

Niniejsze badanie wykazało istotnie wyższą glikemię na czczo u ankietowanych pracujących zmianowo.
Jest to prawdopodobnie spowodowane spożywaniem dodatkowych posiłków, także w nocy, oraz zwiększoną wątrobową produkcją glukozy [13]. W chińskim badaniu dotyczącym emerytowanych pracowników [14] wykazano wyższą glikemię na czczo w grupie emerytów, którzy w przeszłości pracowali zmianowo. Glikemia poposiłkowa nie różniła się między grupami — można przypuszczać, że chorzy modyfikowali wstrzyknięcia insuliny lub przyjmowanie leków, tak aby dostosować je do posiłków.

Odsetek $\mathrm{HbA}_{1 c}$ także się nie różnił, co oznacza, że praca zmianowa w niewielkim stopniu wpływa na wyrównanie glikemii u chorych z cukrzycą typu 2 .

Wskaźnik masy ciała nie wykazywał różnic w obydwu grupach. Jednakże ponad połowa respondentów przyznaje, że od rozpoczęcia pracy zmianowej przybrali na wadze. W wielu publikacjach wykazano istotny związek pomiędzy pracą zmianową a wzrostem masy 
ciała [15-17]. Można więc podejrzewać, że brak różnic w BMI wynika z krótkiego okresu prowadzenia badania lub też z młodszego wieku pracowników zmianowych.

Ważnym problemem u pacjentów pracujących w nocy lub w nieregularnych, zmiennych godzinach są zaburzenia snu - od problemów z zasypianiem, przez niesatysfakcjonującą jakość snu, aż do całkowitej bezsenności [18-22]. Dostępne badania sugerują związek gorszej jakości snu z rozwojem insulinooporności [3]. Problem ten wpływa nie tylko na przebieg i leczenie choroby podstawowej, upośledza on również funkcjonowanie pacjenta w wielu strefach życia, może prowadzić do wykluczenia społecznego (zaburzenia funkcjonowania społecznego zgłasza 6,38\% ankietowanych), a nawet do depresji (4,26\% badanych). Odnotowano także inne zaburzenia, z których najczęściej wymieniano brak koncentracji, zmęczenie, rozdrażnienie, nerwowość $[23,24]$. Wszystkie te trudności odbijają się z całą pewnością na jakości życia chorych, która jest gorsza u pracowników zmianowych. Ma to istotne znaczenie, ponieważ jakość życia pacjenta to jeden z najważniejszych wskaźników sukcesu terapeutycznego [25, 26].

Wszystkie te czynniki mogą obniżać stopień przestrzegania zaleceń lekarskich (compliance) [27]. Gorszy compliance skutkuje częstszym występowaniem odległych powikłań cukrzycy [28].

Do zalet badania należy niewątpliwie osobiste zaangażowanie ankietera $w$ rozmowę $z$ każdym respondentem z osobna. Obecność ankietera często zapobiega błędnemu wypełnieniu kwestionariusza (z powodu słabego wykształcenia respondenta, braku skupienia, nierozumienia) i fałszowaniu wyników badania oraz umożliwia rejestrację wszelkich form niewerbalnych, które zwykle towarzyszą badaniu i pozwalają poznać prawdziwe stanowisko respondenta wobec określonych zagadnień. Jest to jednak proces żmudny, przez co w tym samym czasie można przebadać znacznie mniejszą zbiorowość niż podczas samodzielnego wypełniania kwestionariuszy przez pacjentów. Z tego powodu ankiety $\mathrm{w}$ badanej grupie zostały przeprowadzone jednokrotnie. Z całą pewnością powtórzenie ankiety po pewnym czasie poprawiłoby wiarygodność wyników oraz wykluczyło zmiany parametrów wyrównania wynikające z innych czynników losowych.

\section{Wnioski}

Praca zmianowa w niewielkim stopniu wpływa na wyrównanie glikemii u chorego na cukrzycę typu 2. Natomiast zaburzając rytm okołodobowy, oddziałuje na jakość życia i snu oraz regularność spożywania posiłków u chorego na cukrzycę typu 2. W związku z tym leczenie osoby chorej na cukrzycę typu 2 pracującej w systemie zmianowym może okazać się szczególnie wymagające.

\section{Oświadczenie o konflikcie interesów} Autorzy nie zgłaszają konfliktu interesów.

\section{PIŚMIENNICTWO}

1. Shaw J.E., Sicree R.A., Zimmet P.Z. Global estimates of the prevalence of diabetes for 2010 and 2030. Diabetes Res. Clin. Pract. 2010; 87: 4-14.

2. Antunes L.C., Levandovski R., Dantas G., Caumo W., Hidalgo M.P. Obesity and shift work: chronobiological aspects. Nutr. Res. Rev. 2010; 23: 155-168

3. Van Cauter E. Sleep disturbances and insulin resistance. Diabet. Med. E-pub ahead of print 26 September 2011.

4. Moczulski D. Wielka Interna. Diabetologia. Medical Tribune Polska 2010.

5. Wang X.S., Armstrong M.E., Cairns B.J., Key T.J., Travis R.C. Shift work and chronic disease: the epidemiological evidence. Occup. Med. (Lond) 2011; 61: 78-89.

6. Brudnowska J., Pepłońska B. Night shift work and cancer risk: a literature review. Med. Pr. 2011; 62: 323-338.

7. De Bacquer D., Van Risseghem M., Clays E. i wsp. Rotating shift work and the metabolic syndrome: a prospective study. Int. J. Epidemiol. 2009; 38: 848-854.

8. John Axelsson S.P. Night shift work increases the risk for type 2 diabetes. Evidence-Based Medicine 2012.

9. Brum M.C., Filho F.F., Schnorr C.C., Bottega G.B., Rodrigues T.C. Shift work and its association with metabolic disorders. Diabetol. Metab. Syndr. 2015; 7: 45.

10. Monk T.H., Buysse D.J. Exposure to Shift Work as a Risk Factor for Diabetes. J. Biol. Rhythms. 2013; 28: 356-359.

11. Fornal-Pawłowska M., Wołyńczyk-Gmaj D., Szelenberger W. Walidacja Ateńskiej Skali Bezsenności [Validation of the Polish version of the Athens Insomnia Scale]. Psychiatr. Pol. 2011; 45: 211-221.

12. Gan Y., Yang C., Tong X. i wsp. Shift work and diabetes mellitus: a meta-analysis of observational studies. Occup. Environ Med. 2015; 72: 72-78.

13. Lennernas M., Hambraeus L., Akerstedt T. Shift related dietary intake in day and shift workers. Appetite 1995; 25: 253-265.

14. Guo Y., Liu Y., Huang X. i wsp. The Effects of Shift Work on Sleeping Quality, Hypertension and Diabetes in Retired Workers. PLoS ONE 2013; 8: e71107.

15. Kivimaki M., Batty G.D., Hublin C. Shift Work as a Risk Factor for Future Type 2 Diabetes: Evidence, Mechanisms, Implications, and Future Research Directions. PLoS Med. 2011; 8: e1001138.

16. van Amelsvoort L.G., Schouten E.G., Kok F.J. Duration of shiftwork related to body mass index and waist to hip ratio. Int. J. Obes. Relat. Metab. Disord. 1999; 23: 973-978.

17. van Drongelen A., Boot C.R., Merkus S.L., Smid T., van der Beek A.J. The effects of shift work on body weight change - a systematic review of longitudinal studies. Scand. J. Work Environ Health 2011; 37: 263-275.

18. Akerstedt T. Shift work and sleep disorders. Sleep 2005; 28: 9-11.

19. Drake C.L., Roehrs T., Richardson G., Walsh J.K., Roth T. Shift work sleep disorder: prevalence and consequences beyond that of symptomatic day workers. Sleep 2004; 27: 1453-1462.

20. Monk T.H., Buysse D.J., Billy B.D. i wsp. Shiftworkers report worse sleep than day workers, even in retirement. J. Sleep Res. 2013; 22: 201-208.

21. Sallinen M., Kecklund G. Shift work, sleep, and sleepiness - differences between shift schedules and systems. Scand. J. Work Environ Health 2010; 36: 121-133.

22. Ioja S., Weir I.D., Rennert N.J. Relationship between sleep disorders and the risk for developing type 2 diabetes mellitus. Postgrad. Med. 2012; 124: 119-129.

23. Tunceli K., Bradley C.J., Nerenz D. i wsp. The impact of diabetes on employment and work productivity. Diabetes Care 2005; 28 : 2662-2667. 
24. Hempler N.F., Ekholm O., Willaing I. Differences in social relations between persons with type 2 diabetes and the general population. Scand. J. of Public Health 2013; 41: 340-343.

25. Haus E., Smolensky M. Biological clocks and shift work: circadian dysregulation and potential long-term effects. Cancer Causes Control. 2006; 17: 489-500
26. Scott A.J., LaDou J. Shiftwork: effects on sleep and health with recommendations for medical surveillance and screening. Occup. Med. 1990; 5: 273-299.

27. Delamater A.M. Improving patient adherence. Clinical Diabetes 2006; 24: 71-77.

28. Chatterjee J.S. From compliance to concordance in diabetes. J. Med. Ethics 2006; 32: 507-510. 